\title{
The Abilities of Bacteria and Yeast Isolated from Vermicompost Water Extract to Inhibit Alternaria solani in vitro and Early Blight Disease on Tomato
}

\author{
Noor Istifadah*, Retno Anjani Putri \& Sri Hartati \\ Departement of Plant Pests and Diseases, Agriculture Faculty, Universitas Padjadjaran, Jatinangor, West Java 45363 \\ *Corresponding Author : n.istifadah@unpad.ac.id
}

Received December 24, 2021; revised December 30, 2021; accepted January 04, 2022

\begin{abstract}
Early blight disease (Alternaria solani Sor) is one of limiting factors in tomato production. Bacteria and yeast are potential for biocontrol of plant diseases. Sources to obtain biocontrol agens is water extract of organic matters. The objective of this study was to examine the abilities of bacteria and yeast isolated from vermicompost water extract in inhibiting the growth of A. solani in vitro and suppressing the pathogen infection in tomato fruits and leaves. Two types of vermicompost used in this study were cattle manure vermicompost and goat manure vermicompost. The isolation of bacteria and yeast from the vermicompost water extract resulted in 14 isolates, which were 10 isolates from cattle manure vermicompost and four isolates from goat manure vermicompost. Among the isolates, six isolates (three yeast and three bacterial isolates) inhibited the growth of A. solani in vitro by $42.8 \%-79.1 \%$. In tomato fruits, five isolates inhibited A. solani infection by $70.6 \%-$ $100.0 \%$. In tomato plants, four isolates suppressed early blight disease in tomato leaves by $56.2 \%-83.5 \%$. The isolate that showed consistent effects in vitro as well as in vivo was bacterial isolate KB 3. This isolate was potential as biocontrol agent of tomato diseases caused by A. solani.
\end{abstract}

Keywords: Biocontrol, isolation, cattle manure, goat manure, tomato fruit

\section{ABSTRAK \\ Kemampuan Isolat Bakteri dan Khamir Asal Air Rendaman Kascing untuk Menghambat Alternaria solani in vitro dan Penyakit Bercak Cokelat pada Tomat}

Penyakit bercak cokelat (Alternaria solani Sor.) merupakan penyakit penting pada tanaman tomat. Bakteri dan khamir sangat berpotensi untuk dijadikan sebagai agens biokontrol penyakit tanaman. Salah satu sumber untuk mendapatkan mikrob agens biokontrol adalah air rendaman bahan organik. Penelitian ini dilakukan untuk mendapatkan isolat bakteri dan khamir dari air rendaman kascing yang dapat menghambat pertumbuhan jamur A. solani secara in vitro dan menekan infeksinya pada buah dan daun tomat. Bakteri dan khamir diisolasi dari air rendaman kascing berbahan dasar kotoran sapi dan kascing berbahan dasar kotoran domba. Hasil isolasi diperoleh 14 isolat yaitu 10 isolat dari air rendaman kascing berbahan dasar kotoran sapi dan empat isolat dari kascing berbahan dasar kotoran domba. Pada percobaan in vitro terdapat tiga isolat bakteri dan tiga isolat khamir yang menghambat pertumbuhan $A$. solani dengan kisaran penghambatan sebesar $42,8 \%-79,1 \%$. Pada percobaan di buah tomat, lima isolat yang diuji dapat menekan infeksi A. solani sebesar 70,6\% - 100,0\%. Pada tanaman tomat, dua isolat bakteri dan satu isolat khamir dapat menekan penyakit bercak cokelat $56,2 \%-83,5 \%$. Isolat yang menunjukkan efek penekanan yang konsisten pada percobaan in vitro dan in vivo adalah isolat bakteri KB3. Isolat ini berpotensi untuk dikembangkan sebagai agens biokontrol penyakit karena A. solani pada tanaman tomat.

Kata Kunci: biokontrol, isolasi, buah tomat, kotoran sapi, kotoran domba

\section{PENDAHULUAN}

Tomat merupakan salah satu komoditas hortikultura penting di Indonesia. Buah tomat dapat dikonsumsi secara langsung sebagai buah atau campuran masakan maupun sebagai bahan untuk industri makanan seperti saus. Guna memenuhi pasokan buah tomat di pasaran, tanaman tomat banyak dibudidayakan di daerah dataran menengah maupun tinggi.

Kendala utama dalam budidaya tomat di antaranya adalah adanya serangan hama dan penyakit tanaman. Salah satu penyakit yang sering menimbulkan kerugian pada pertanaman tomat adalah penyakit bercak cokelat yang disebabkan oleh jamur Alternaria solani Sor. Jamur patogen ini dapat menginfeksi hampir semua bagian tanaman tomat antara lain pada daun, ranting atau batang maupun buah tomat. Gejala penyakit pada daun berupa bercak konsentris berwarna kecokelatan dan jaringan di sekitarnya biasanya juga akan menguning (khlorosis). Pada gejala lanjut, bercak akan membesar dan menyatu sehingga daun menjadi mengering. Pada buah yang terinfeksi tampak gejala berupa busuk melekuk yang pada kondisi lembab pada permukaannya tampak adanya lingkaran-lingkaran konsentris. Gejala biasanya muncul pada bagian dekat tangkai sehingga buah terinfeksi akan mudah gugur (Agrios, 2005; Adhikari et al., 2017). Dilaporkan bahwa infeksi $A$. solani pada tanaman tomat dapat menimbulkan kerugian mencapai 79\% (Chaerani \& Voorrips, 2006).

Cara pengendalian yang sering digunakan untuk menekan penyakit bercak cokelat adalah penyemprotan dengan fungisida. Penggunaan pestisida termasuk fungisida secara terus menerus 
dapat menimbulkan berbagai dampak negatif baik seperti pencemaran lingkungan, akumulasi residu pestisida serta timbulnya patogen yang resisten (Mahmood, 2016). Mempertimbangkan berbagai dampak negatif tersebut, maka perlu dikembangkan cara pengendalian yang ramah lingkungan di antaranya adalah pengendalian secara biologi atau biokontrol.

Bahan organik merupakan salah satu sumber mikrob agens pengendali biologi penyakit tanaman. Salah satu bahan organik yang berpotensi sebagai sumber mikrob menguntungkan adalah kascing yaitu hasil dekomposisi bahan organik oleh cacing tanah dan mikrob yang berasosiasi dengannya. Jenis cacing yang banyak dibudidayakan antara lain Lumbricus, Pheretima, dan Periony. Cacing tersebut merupakan bahan yang digunakan sebagai pakan ikan, bahan obat dan juga kosmetik. Pakan yang digunakan untuk budidaya cacing tanah dapat berupa kotoran sapi, kotoran kambing, sampah rumah tangga atau campuran berbagai bahan (Prihatman, 2000). Hasil dekomposisi cacing tanah bertekstur remah dengan kapasitas menahan air dan kandungan unsur hara yang tinggi serta mengandung mikrob yang menguntungkan. Oleh karena itu, kascing merupakan bahan pembenah tanah dan pupuk organik (Pathma \& Sakthivel, 2012).

Selain sebagai pupuk organik, kascing atau air rendamannya (vermicompost water extract) juga dapat digunakan dalam pengendalian penyakit tanaman. Aplikasi kascing pada medium tanam dapat menekan berbagai penyakit tular tanah (Ersahin, 2011; Pathma \& Sakhtivel, 2012). Penyemprotan air rendaman kascing juga dapat menekan penyakit tular udara (Sarma et al., 2010; Ersahin, 2011). Bahan dasar dalam pembuatan kascing dapat berpengaruh terhadap kemampuannya dalam menekan penyakit dan kandungan mikrob yang ada di dalamnya. Kascing berbahan dasar kotoran hewan sapi lebih baik dalam menekan penyakit layu Fusarium pada tanaman tomat dibandingkan yang berbahan dasar sampah rumah tangga (Istifadah, 2001).

Penekanan penyakit yang dihasilkan akibat aplikasi kascing pada umumnya karena kascing mengandung mikrob yang bersifat antagonistik terhadap patogen tanaman (Sarma et al., 2010; Pathma \& Sakhtivel, 2012). Istifadah et al. (2021) mengisolasi jamur dari air rendaman kascing dan mendapatkan beberapa isolat yang dapat menghambat A. solani secara in vitro dan menekan penyakit bercak cokelat pada tanaman tomat. Penelitian yang dibahas di sini adalah potensi bakteri dan khamir isolat air rendaman kascing terhadap pertumbuhan $A$. solani secara in vitro dan penyakit bercak cokelat pada buah dan tanaman tomat.

\section{BAHAN DAN METODE}

\section{Isolasi dan Uji Patogenesitas Jamur A. solani}

Jamur patogen $A$. solani diisolasi dari daun tomat yang bergejala penyakit bercak cokelat. Daun yang bergejala dipotong sekitar $1 \mathrm{~cm}^{2}$ pada bagian batas jaringan sakit dan sehat. Potongan daun bergejala kemudian didesinfestasi dengan merendamnya pada larutan khloroks $2 \%$ selama dua menit, kemudian dalam alkohol $70 \%$ selama 30 detik. Setelah itu, potongan daun dikeringanginkan di atas filter paper steril dan setelah kering diletakkan pada petridish berisi media Potato Dextrose Agar (PDA) yang telah diberi antibiotik chloramphenicol $0,1 \%$. Koloni jamur yang tumbuh dan memiliki karakteristik koloni A. solani dimurnikan pada media PDA yang baru. Isolat jamur yang peroleh diuji patogenisitasnya dengan cara menempelkan potongan biakan pada buah tomat yang telah dilukai.

\section{Isolasi Mikrob dari Air Rendaman Kascing}

Kascing yang digunakan dalam penelitian ini adalah kascing berbahan dasar kotoran sapi dan kascing berbahan dasar kotoran domba. Air rendaman kascing dibuat dengan mencampurkan kascing dengan air pada perbandingan $(1: 4, \mathrm{v} / \mathrm{v})$. Campuran tersebut disimpan dalam wadah tertutup selama dua minggu dan setiap dua hari sekali diaduk. Sebelum digunakan air rendaman kascing disaring agar terpisah dari endapannya. Untuk mengisolasi bakteri dan khamir, air rendaman kascing diencerkan secara berseri. Isolasi dilakukan dengan mengambil suspensi pada pengenceran $10^{-5}$ dan $10^{-6}$ sebanyak $200 \mu \mathrm{l}$ kemudian ditambahkan media sebanyak $10 \mathrm{ml}$. Media yang digunakan antara lain Malt Extract Agar (untuk isolasi khamir) dan Nutrient Agar (untuk isolasi bakteri). Isolat mikrob yang memiliki karakteristik berbeda, dimurnikan pada medium agar yang baru.

\section{Pengujian secara in Vitro}

Pengujian kemampuan antagonisme bakteri dan khamir asal air rendaman kascing secara in vitro dilakukan dua tahap yaitu seleksi awal dan pengujian lanjutan. Pengujian dilakukan dengan metode dual culture yang mana isolat bakteri atau khamir digoreskan membentuk garus lurus pada medium half strength PDA dengan jarak $3 \mathrm{~cm}$ dari potongan biakan A. solani. Isolat yang pada seleksi awal menunjukkan penghambatan lebih dari $50 \%$, diuji kembali dengan menggunakan rancangan acak lengkap untuk mengonfirmasi kemampuannya.

Pengamatan dilakukan pada tujuh hari setelah inokulasi dengan cara mengukur jari-jari koloni $A$. solani yang ke arah koloni bakteri atau khamir. Lebar zona bening yang terbentuk antara koloni patogen dengan koloni bakteri atau khamir juga diukur.

\section{Pengujian pada Buah Tomat}

Isolat bakteri dan khamir hasil seleksi kemudian diuji kemampuannya untuk menghambat infeksi A. solani pada buah tomat. Percobaan menggunakan rancangan acak kelompok dengan empat ulangan. Buah tomat yang digunakan dicuci dengan air mengalir, kemudian permukaannya 
didesinfeksi dengan alkohol 70\%. Bagian buah yang akan diinokulasi dilukai dengan ujung jarum steril. Potongan biakan jamur A. solani (diameter $0,5 \mathrm{~cm}$ ) ditumpukkan secara berhadapan pada potongan biakan bakteri atau khamir (diameter $0,5 \mathrm{~cm}$ ), kemudian dilekatkan pada jaringan buah tomat yang telah dilukai dengan bantuan selotip dan cling wrap. Pada kontrol, potongan biakan patogen ditumpukkan pada potongan media agar (Istifadah dkk., 2020). Buah tomat yang telah diberi perlakuan ditempatkan pada empat kotak plastik berbeda yang merupakan ulangannya. Guna menjaga kelembaban, di setiap pojok dari kotak diberi kapas basah. Potongan biakan patogen dan selotip dibuka lima hari setelah inokulasi, ketika buah tomat pada kontrol telah mulai bergejala. Diamater gejala yang terbentuk kemudian diukur dan dibandingkan dengan kontrol untuk menentukan persentase penghambatannya.

\section{Pengujian Mikrob pada Tanaman Tomat}

Percobaan menggunakan rancangan acak kelompok dengan perlakuan isolat mikrob antagonis, kontrol dan fungisida (berbahan aktif mancozeb) sebagai pembanding. Perbanyakan bakteri atau khamir yang digunakan pada percobaan ini dilakukan dengan cara berikut ini. Biakan bakteri atau khamir dari agar miring ditambah $10 \mathrm{ml}$ air steril, kemudian suspensi dimasukkan ke dalam tabung reaksi steril dan dihomogenkan dengan vortex stirrer. Suspensi sel bakteri atau khamir tersebut sebanyak $500 \mu \mathrm{l}$ diratakan ke seluruh permukaan medium half strength PDA agar yang ada pada petridish. Biakan kemudian diinkubasikan selama tiga hari untuk bakteri dan lima hari untuk khamir. Setelah itu, suspensi bakteri atau khamir yang digunakan untuk perlakuan tanaman tomat dibuat dengan menambahkan $20 \mathrm{ml}$ air steril yang telah ditambah Tween $80(0,1 \%)$ ke dalam petridish yang berisi biakan bakteri atau khamir. Biakan yang menutupi seluruh permukaan agar dilepaskan dengan bantuan jarum öse, kemudian suspensi dimasukkan ke dalam tabung reaksi. Suspensi yang diperoleh dihomogenkan dengan vortex stirrer. Konsentrasi suspensi bakteri yang digunakan adalah $10^{7} \mathrm{cfu} / \mathrm{ml}$, sedangkan untuk suspensi khamir $10^{7} \mathrm{sel} / \mathrm{ml}$.

Sehari sebelum inokulasi patogen, anak daun majemuk paling ujung (anak daun terlebar) pada daun keempat, kelima dan keenam dari tanaman tomat (berumur delapan minggu) disemprot dengan suspensi mikrob yang diuji sampai merata. Tanaman yang telah diberi perlakuan kemudian disungkup agar terjaga kelembaban di sekitarnya. Pada perlakuan kontrol dilakukan penyemprotan dengan menggunakan air steril, sedangkan pada perlakuan pembanding daun disemprot dengan suspensi fungisida dengan konsentrasi anjuran. Pada bagian daun yang akan diinokulasi patogen dilukai dengan menggunakan ujung jarum steril. Potongan biakan patogen (diameter Tabel 1. Kemampuan bakteri antagonis asal kascing untuk menghambat A. solani secara in vitro
0,5 cm) diletakkan di atas selotip kemudian ditempelkan pada bagian yang telah dilukai dengan bantuan plastic wrap. Tanaman tomat yang telah diinokulasi patogen disungkup plastik selama dua hari. Biakan patogen dilepas lima hari setelah inokulasi ketika daun pada kontrol telah menunjukkan gejala penyakit (Istifadah dkk., 2020).

Luas gejala yang muncul pada daun yang diinokulasi dihitung menggunakan milimeter blok. Pengamatan dilakukan setiap dua hari sekali. Data luas gejala digunakan untuk perhitungan Area Under The Disease Progress Curve (AUDPC) (Campbell \& Madden, 1990). Persentase penekanan penyakit dihitung berdasarkan nilai AUDPC pada perlakuan mikrob atau fungisida dibandingkan dengan kontrol.

\section{Analisis Data}

Data yang diperoleh dianalisis menggunakan Analysis of Variance (ANOVA) menggunakan program Statistical Product and Service Solutions (SPSS) Version 21. Apabila hasil berbeda nyata antar perlakuan, dilakukan uji lanjut dengan Tukey's Honest Significant Difference (HSD) pada taraf 5\%.

\section{HASIL DAN PEMBAHASAN}

\section{Penghambatan Patogen secara in Vitro}

Isolasi mikrob dari air rendaman kascing menghasilkan 14 isolat mikrob yang koloninya menyerupai koloni bakteri atau khamir. Air rendaman kascing berbahan dasar kotoran sapi menghasilkan 10 isolat, sedangkan air rendaman kascing yang berasal dari kotoran kambing menghasilkan empat isolat. Perbedaan jumlah dan jenis isolat yang terisolasi dari kascing dapat dipengaruhi oleh jenis cacing dan pakan yang digunakan dalam pembuatan kascing (Liou, et al., 2014). Istifadah (2001) juga menemukan bahwa kascing berbahan dasar kotoran sapi menghasilkan jumlah isolat mikrob yang lebih banyak daripada kascing berbahan dasar sampah rumah tangga.

Pada seleksi awal kemampuan antagonisme secara in vitro menunjukkan bahwa delapan isolat hanya dapat menghambat pertumbuhan A. solani sampai $12.8 \%$, sementara enam isolat lainnya menunjukkan tingkat penghambatan pertumbuhan patogen lebih dari 50\%. Berdasarkan hasil pengamatan secara mikroskopis, diketahui bahwa tiga isolat merupakan khamir dan tiga isolat lainnya merupakan bakteri. Isolat yang pada seleksi awal dapat menghambat pertumbuhan patogen lebih dari $50 \%$, diuji kembali untuk mengonfirmasi kemampuan antagonistiknya. Pada pengujian lanjutan, isolat mikrob yang diuji dapat menghambat pertumbuhan $A$. solani sebesar 43,8\% - 79,1\% (Tabel 1). Pada pengujian yang kedua ini, ternyata khamir isolat SB 2 menunjukkan tingkat penghambatan kurang dari $50 \%$ sehingga isolat ini tidak digunakan dalam pengujian secara in vivo. 


\begin{tabular}{lccc}
\hline Perlakuan & Jari-jari Patogen $(\mathrm{mm})$ & Penghambatan $(\%)$ & Zona Hambat $(\mathrm{mm})$ \\
\hline Kontrol & $14,33 \mathrm{~b}$ & 0,0 & 0,00 \\
Isolat SB 1 (khamir) & $5,33 \mathrm{a}$ & 62,8 & 4,7 \\
Isolat SB 2 (khamir) & $6,23 \mathrm{a}$ & 42,8 & 2,7 \\
Isolat SB 10 (khamir) & $4,67 \mathrm{a}$ & 67,4 & 3,0 \\
Isolat SB 7 (bakteri) & $5,33 \mathrm{a}$ & 62,8 & 3,3 \\
Isolat KB 2 (bakteri) & $3,00 \mathrm{a}$ & 79,1 & 5,3 \\
Isolat KB 3 (bakteri) & $4,33 \mathrm{a}$ & 69,8 & 3,0 \\
\hline
\end{tabular}

Keterangan: angka yang diikuti oleh huruf yang sama menunjukkan perlakuan yang tidak berbeda nyata menurut uji Tukey HSD pada taraf $5 \%$.

Penghambatan pertumbuhan patogen oleh isolat bakteri dan khamir yang diuji diduga karena adanya mekanisme antibiosis. Hal ini diindikasikan dengan adanya zona bening di antara koloni mikrob antagonis dan koloni patogen yang lebarnya berkisar antara 2,7-5.3 mm (Tabel 1). Zona hambat tersebut terbentuk karena adanya senyawa antimikrob yang terdifusi ke media sehingga mikrob pada bagian tersebut tidak tumbuh. Khamir (Freimoser et al., 2019) dan bakteri (Raaijmakers et al., 2002) dikenal dapat menghasilkan metabolit sekunder yang dapat menghambat pertumbuhan atau mematikan patogen.

Berdasarkan lebar zona hambat yang terbentuk, sebenarnya kemampuan antibiosis isolatisolat yang diuji masih dalam kategori lemah karena masih kurang dari $6 \mathrm{~mm}$ (Morales et al., 2003). Oleh karena itu, selain adanya mekanisme antibiosis penghambatan jamur patogen juga terjadi karena adanya kemampuan kompetisi dari isolat bakteri atau khamir yang diuji. Beberapa isolat koloninya tampak meluas secara cepat sehingga dapat menyaingi patogen dalam mendapatkan ruang dan nutrisi untuk tumbuh.

\section{Penghambatan Infeksi A. solani pada Buah Tomat} Hasil pengujian pada buah tomat menunjukkan bahwa bakteri dan khamir hasil isolasi dari air rendaman kascing dapat menekan perkembangan penyakit akibat infeksi A. solani pada buah tomat sebesar 70,6\%-100,0\%. Isolat yang menunjukkan penekanan penyakit sampai $100 \%$ adalah satu isolat khamir dan dua isolat bakteri (Tabel 2). Buah tomat yang diberi perlakuan isolat tersebut tidak menunjukkan adanya gejala pembusukan, padahal jaringan buahnya telah dilukai dan diinokulasi patogen (Gambar 1).

Tabel 2. Pengaruh bakteri dan khamir asal air rendaman kascing terhadap infeksi A. solani pada buah tomat (5 hari setelah inokulasi)

\begin{tabular}{lcc}
\hline \multicolumn{1}{c}{ Perlakuan } & Diameter Gejala $(\mathrm{mm})$ & Penghambatan $(\%)$ \\
\hline Kontrol & $4,3 \mathrm{~b}$ & 0,0 \\
Isolat SB 1 (khamir) & $1,3 \mathrm{a}$ & 76,5 \\
Isolat SB 10 (khamir) & $0,0 \mathrm{a}$ & 100,0 \\
Isolat SB 7 (bakteri) & $0,0 \mathrm{a}$ & 100,0 \\
Isolat KB 2 (bakteri) & $1,3 \mathrm{a}$ & 70,6 \\
Isolat KB 3 (bakteri) & $0,0 \mathrm{a}$ & 100,0 \\
\hline
\end{tabular}

Keterangan: angka yang diikuti oleh huruf yang sama menunjukkan perlakuan yang tidak berbeda nyata $\%$ menurut uji Tukey HSD pada taraf $5 \%$.
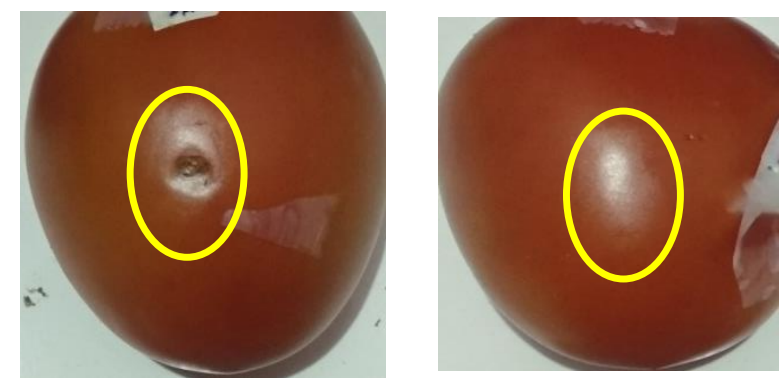

Gambar 1. Gejala infeksi A. solani pada buah tomat. (a) Kontrol; (b) Perlakuan dengan isolat bakteri KB3. 
Sebenarnya pelukaan pada buah tomat sangat mendukung penetrasi jamur patogen ke dalam jaringan. Namun demikian, adanya mikrob antagonis yang diaplikasikan dapat menghambat pertumbuhan dan infeksi patogen. Apabila didasarkan pada pembentukan zona hambatnya pada uji in vitro, sebenarnya potensi antibiosis isolat bakteri dan khamir yang diuji masih dalam kategori lemah, tapi ketika diuji pada buah tomat terdapat dua isolat bakteri dan satu isolat khamir yang menghambat infeksi A. solani pada buah tomat sampai $100 \%$. Penghambatan ini kemungkinan dikarenakan adanya faktor kompetisi. Ketiga isolat tersebut mempunyai pertumbuhan yang cepat dan meluas sehingga dapat berkompetisi dengan patogen dalam mengolonisasi jaringan inang dan mencegah terjadinya infeksi. Freimoser et al. (2019) menyatakan bahwa khamir seperti Sacharomyces cerrevicae dapat mengolonisasi jaringan buah sehingga membentuk lapisan yang dapat menghalangi penetrasi dan juga menghambat pertumbuhan jamur patogen. Ray et al. (2011) juga menyatakan bahwa khamir dan bakteri antagonis yang pertumbuhannya cepat dapat mengolonisasi jaringan dan mengambil nutrisi lebih cepat daripada jamur patogen sehingga menghambat pertumbuhan patogen tersebut. Isolat mikrob antagonis yang efektif dalam menghambat infeksi $A$. solani pada buah tomat pada penelitian ini berpotensi untuk digunakan dalam pengendalian penyakit pascapanen. Pemanfaatan khamir dan bakteri dalam pengendalian penyakit pascapanen telah banyak dikembangkan (Ray et al., 2011).

\section{Penghambatan terhadap Penyakit Bercak Cokelat pada Tanaman Tomat}

Hasil percobaan pada tanaman tomat menunjukkan bahwa di antara lima isolat mikrob antagonis yang diuji, hanya empat isolat yang dapat menghambat perkembangan penyakit bercak cokelat pada tanaman tomat sebesar 55,9\% - 83,4\% (Tabel 3). Daun tanaman tomat yang diinokulasi khamir atau bakteri antagonis ini hanya menunjukkan perkembangan bercak yang kecil, sedangkan pada daun yang disemprot menggunakan air (kontrol) gejala penyakit bercak cokelat bertambah luas dan jaringan di sekitarnya menguning atau khlorosis (Gambar 2).

Tabel 3. Pengaruh isolat bakteri dan khamir asal air rendaman kascing terhadap perkembangan penyakit bercak cokelat pada tanaman tomat

\begin{tabular}{lcc}
\hline \multicolumn{1}{c}{ Perlakuan } & Nilai AUDPC & Penghambatan (\%) \\
\hline Kontrol + & $194,9 \mathrm{~d}$ & 0,0 \\
Pestisida & $57,6 \mathrm{a}$ & 70,5 \\
Isolat SB 1 (khamir) & $51,4 \mathrm{a}$ & 73,6 \\
Isolat SB 10 (khamir) & $160,6 \mathrm{c}$ & 17,6 \\
Isolat SB 7 (bakteri) & $85,9 \mathrm{~b}$ & 55,9 \\
Isolat KB 2 (bakteri) & $32,4 \mathrm{a}$ & 83,4 \\
Isolat KB 3 (bakteri) & $40,7 \mathrm{a}$ & 79,1 \\
\hline
\end{tabular}

Keterangan: angka yang diikuti oleh huruf yang sama berarti tidak berbeda nyata berdasarkan uji Tukey. pada taraf $5 \%$. Nilai AUDPC dihitung berdasarkan data luas bercak $\left(\mathrm{mm}^{2}\right)$ dari lima kali pengamatan setiap dua hari sekali.
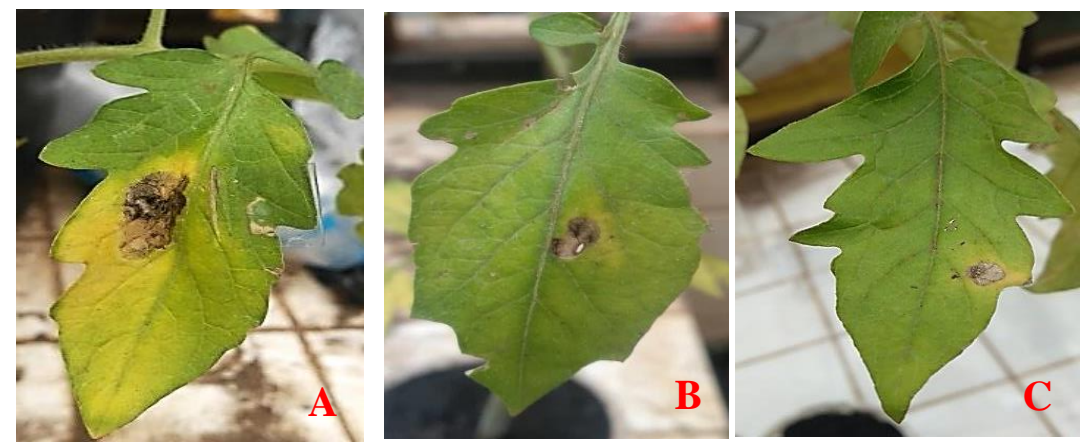

Gambar 2. Gejala penyakit bercak cokelat pada daun tomat: (A) Kontrol; (B) Perlakuan dengan isolat khamir SB1; (C) Perlakuan dengan isolat bakteri KB 2

Kemampuan isolat bakteri dan khamir dalam menekan penyakit bercak cokelat pada tanaman tomat kemungkinan dapat melalui berbagai mekanisme.
Mikrob antagonis yang diaplikasikan sebelum inokulasi patogen dapat mengolonisasi permukaan daun sehingga menghambat perkecambahan spora 
jamur patogen (Sangiogo et al., 2018). Isolat mikrob yang dapat menekan penyakit bercak cokelat ini dapat menghasilkan zona hambat secara in vitro sehingga kemungkinan penekanan penyakit dapat pula dikarenakan dihasilkannya metabolit sekunder yang dapat menghambat patogen. Legein et al. (2020) menyatakan bahwa mekanisme yang terlibat dalam penekanan penyakit pada filosfer di antaranya adalah adanya metabolit sekunder yang bersifat antimikrob.

Selain karena adanya antagonisme secara langsung, penekanan penyakit bercak cokelat oleh isolat bakteri dan khamir asal air rendaman kascing dapat pula karena adanya kemampuan isolat dalam menginduksi ketahanan tanaman terhadap penyakit. Kemampuan bakteri (Pieterse et al., 2014) dan khamir (Freimoser et al., 2019) untuk menginduksi ketahanan tanaman terhadap penyakit telah banyak dilaporkan. Hasil penelitian Istifadah \& Herawati (2021) menunjukkan bahwa bakteri yang diisolasi dari air rendaman bahan organik ada yang dapat menginduksi ketahanan tanaman tomat terhadap penyakit bercak cokelat yang dindikasikan dengan pemisahan tempat antara mikrob antagonis dengan patogennya serta adanya peningkatan aktivitas $\beta$-glucanase dan chitinase.

Pada percobaan di tanaman tomat, terdapat satu isolat khamir SB 10 yang tidak menunjukkan efek penekanan, padahal pada pengujian in vitro dapat menghambat $A$. solani bahkan pada buah tomat dapat menekan terjadinya infeksi A. solani sampai $100 \%$. Hal ini terjadi kemungkinan karena isolat tersebut tidak mampu berdaptasi dan berkembang pada daun tomat secara baik sehingga kemampuan antagonistiknya tidak terlihat secara optimal. BessetManzoni et al. (2019) melaporkan bahwa antagonis yang menunjukkan kemampuan antagonisme yang baik pada uji in vitro tidak selalu efektif ketika diuji pada tanaman. Sebaliknya, mikrob yang kurang efektif dalam pengujian in vitro ternyata dapat efektif menekan penyakit pada tanaman. Hal ini karena mekanisme penekanan penyakit selain melalui antagonisme langsung dapat pula secara tidak langsung melalui induksi ketahanan tanaman.

Hasil percobaan secara keseluruhan menunjukkan bahwa air rendaman kascing merupakan sumber mikrob yang bersifat antagonistik terhadap patogen tanaman. Beberapa isolat bakteri dan khamir yang diisolasi dari air rendaman kascing dapat menghambat pertumbuhan A. solani secara in vitro dan infeksinya pada buah dan daun tomat. Pada peneltian ini, tidak semua isolat yang dapat menghambat patogen secara in vitro dan menekan infeksi pada buah juga efektif menekan penyakit bercak cokelat pada daun tomat. Isolat yang konsisten menunjukkan penghambatan terhadap pertumbuhan $A$. solani dan perkembangan infeksinya adalah isolat bakteri KB 3. Isolat ini dapat menekan infeksi $A$. solani pada buah sampai $100 \%$ dan menekan penyakit bercak cokelat pada daun tomat sebesar $79,1 \%$. Isolat ini berpotensi untuk dikembangkan sebagai agens biokontrol penyakit karena $A$. solani pada tanaman tomat.

\section{KESIMPULAN}

Isolasi dari air rendaman kascing menghasilkan 14 isolat bakteri dan khamir, enam isolat di antaranya dapat menghambat pertumbuhan $A$. solani secara in vitro sebesar 42,8\%-79.1\%. Pada uji di buah tomat, tiga isolat bakteri dan dua isolat khamir dapat menghambat infeksi $A$. solani pada buah tomat sebesar 70,6\%-100\%. Pada pengujian di tanaman tomat terdapat empat isolat yang dapat menekan penyakit sebesar $56,2 \%-83,7 \%$.

\section{UCAPAN TERIMA KASIH}

Penelitian ini adalah salah satu bagian dari serangkaian penelitian dengan skema "Penelitian Dasar Unggulan Perguruan Tinggi (PDUPT)" yang didanai oleh DRPM-DIKTI.

\section{DAFTAR PUSTAKA}

Adhikari P, Oh Y, \& Panthee DR. 2017. Current status of early blight resistance in tomato: an update. International Journal Molecular Science. 18:1-22.

Agrios GN. 2005. Plant Pathology. Fifth Edition, Academic Press. San Diego, California.

Besset-Manzoni Y, Joly P, Brutel A, Gerin F, Soudière O, Langin T, \& Prigent-Combaret C. 2019. Does in vitro selection of biocontrol agents guarantee success in planta? A study case of wheat protection against Fusarium seedling blight by soil bacteria. PLoS One. 5: 14 (12): e0225655. doi: 10.1371/journal .pone. 0225655 .

Campbell LC \& Madden VL. 1990. Introduction Plant Disease Epidemiology. John Wiley and Son. USA.

Chaerani R \& Voorrips RE. 2006. Tomato early blight (Alternaria solani): the pathogen, genetics, and breeding for resistance. J. Gen. Plant Pathol. 72: 335-347.

Ersahin Y. 2010. The use of vermicompost products to control plant disease and pests. Biology of Earthworms. 191-213. DOI: 10.1007/978-3642-14636-7_12.

reimoser FM, Rueda-Mejia MP, Tilocca B, \& Migheli Q. 2019. Biocontrol yeasts: mechanisms and applications. World J Microb Biot. 35:154.

Istifadah N. 2001. Kemampuan kascing dalam menekan perkembangan penyakit layu Fusarium pada tanaman tomat. Agrikultura. 12: 16-21.

Istifadah N \& Herawati L. 2021. The potential of microbes isolated from spent substrate of shiitake and oyster mushrooms to induce resistance against early blight disease in tomatoes. Advances in Biological Sciences Research. 15: 80-85 
Istifadah N, Novilaressa PG, Widiantini F, \& Hartati S. 2020. Keefektifan bakteri dan khamir asal air rendaman kompos dalam menekan perkembangan penyakit bercak cokelat (Alternaria solani Sorr.) pada tomat. Jurnal Agrikultura. 31 (1): 52-60.

Istifadah N, Putri RA, Widiantini F, \& Hartati S. 2021. The potential of fungal isolates from vermicompost water extract to inhibit Alternaria solani in vitro and suppress early blight disease in tomato. Advances in Biological Sciences Research. 13: 46-50.

Kohl J, Koolnar R, \& Ravensberg WJ. 2019. Mode of action of microbial biological plant disease: relevance beyond efficacy. Front. Plant Science. 10:845.

Legein M, Smets W, Vandenheuvel D, Eilers T, Muyshondt B, Prinsen E, Samson R \& Lebeer S. 2020. Modes of action of microbial biocontrol in the phyllosphere. Front. Microbiol. 11:1619. doi: 10.3389/fmicb. 2020. 01619.

Liou G, Strauss S, McClean A, \& Kluepfel D. 2014. The Identification of Bacteria Species in Vermicompost. USDA Agricultural Research Service.

Mahmood I, Imadi SR, Shazadi K, Gul A, \& Hakeem KR. 2016. Effects of pesticides on

Akhtar MS, Abdullah SNA (Eds.) Plant, Soil and Microbes. Volume 1: Implications in Crop Science. Springer International. Switzerland. Morales G, Sierra P, Mancilla, Parades A, Loyola LA, Gallardo O, Borquez J. 2003. Secondary metabolites from four medicinal plants from Northern Chile, antimicrobial activity, and biotoxicity against Artemia salina. Journal Chile Chem. 48(2) doi: 10.4067/S0717 -97072003000200002 .

Pathma J \& Sakthivel N. 2012. Molecular and functional characterization of bacteria isolated from straw and goat manure based vermicompost. Applied soil ecology. 70: 3347.

Pieterse CMJ, Zamioudis C, Berendsen RL, Weller DM, VanWees SCM, \& Bakker PAHM. 2014. Induced systemic resistance by beneficial microbes. Annu. Rev. Phytopathol. 52:347-75.

Prihatman K. 2000. Budidaya Cacing Tanah. Deputi Bidang Pendayagunaan dan Pemasyarakatan Iptek, Kemeristek. Jakarta.

Raaijmakers JM \& Souza MJD. 2002. Antibiotic production by bacterial biocontrol agents. AntoniLeeuwenhoek Int J. 81:537-547.

Ray RC, Swain MR, Smita H., Panda SH, and Lata. 2011. Microbial Control of Postharvest Diseases of Fruits, Vegetables, Roots, and Tubers. Pp 311-355 in Singh A, Parmar N, Kuhad RC (eds.). Bioaugmentation, Biostimulation and Biocontrol, Soil Biology. Springer-Verlag, Berlin (Heidelberg).

Sangiogo M, Rodriguez DP, Moccellin R, Bermudez JMM, Correa BO, \& Moura AB. 2018. Foliar spraying with bacterial biocontrol agents for the control of common bacterial blight of bean. Pesquisa Agropecuari Brasileira. 53(10). doi: 10.1590/S0100-204X2018001000003.

Sarma BK, Singh P, Pandey SK, \& Singh HB. 2010. Vermicompost as modulator of plant growth and disease suppression. Dynamic Soil, Dynamic Plant, 4 (Spl. Issue 1): 58-66.

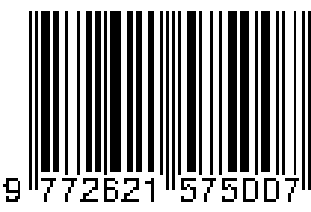

